Journal of Engineering and Applied Sciences 14 (Special Issue 4): 7329-7339, 2019

ISSN: 1816-949X

(C) Medwell Journals, 2019

\title{
A Review on Color Removal from Industrial Wastewater using Different Types of Coagulants
}

\author{
${ }^{1,2}$ Geraldine Chan Sue Ching, ${ }^{1}$ Daphne Lemoi Ak Tawan, ${ }^{1}$ Viviana Elliem Ak Harry and \\ ${ }^{2}$ Kwok Feng Chong \\ ${ }^{1}$ Faculty of Chemical Engineering, Universiti Teknologi MARA (UiTM), 94300 Kota Samarahan, \\ Sarawak, Malaysia, geraldinechansc@uitm.edu.my \\ ${ }^{2}$ Faculty of Industrial Sciences and Technology, Universiti Malaysia Pahang (UMP), \\ Lebuhraya Tun Razak, 26300 Kuantan, Pahang Darul Makmur, Malaysia
}

\begin{abstract}
Coagulation and flocculation are two of the most common chemical treatment methods used in wastewater treatment. The objective of this research is to study the effectiveness of coagulation-flocculation method for the color removal from industrial wastewater by using a different type of coagulants. In this research, we had study and compare the five types of coagulants that were used in past experiment which are Magnesium Chloride $\left(\mathrm{MgCl}_{2}\right)$, Aluminium sulphate (Alum) and Polyaluminium Chloride (PAC), Ferric Chloride $\left(\mathrm{FeCl}_{3}\right)$ and Ferrous Sulphate $\left(\mathrm{FeSO}_{4}\right)$ to remove Remazol Black B (RBB), Remazol BrilliantBlue (RBBR), Remazol Brilliant Red F3B (RBRF3B), leachate, Disperse Red 60 (DR 60) and Brilliant Green (BG) dye. As the coagulant aid, polyelectrolyte, Koaret PA 3230 and Praestol was used. To obtain the optimum condition of the highest color removal of reactive dye, this research focuses on the effect of $\mathrm{pH}$, coagulant dosage, settling time and mixing time. Among all the studies, we have come to a conclusion and conclude that PAC was the most effective coagulant in treating each dye with the color removal among the coagulants used.
\end{abstract}

Key words: Coagulation, flocculation, industrial wastewater, color removal, polyelectrolyte, reactive dye

\section{INTRODUCTION}

Wastewater derived from the production of dyes is highly variable in composition and contains a large number of different compounds such as raw materials (annilies), intermediate products and even the dye itself (Sarasa et al., 1998). Industrial wastewater generally, contains contaminants such as suspended solids, dissolved organic matters, heavy metals and cyanides at levels considered hazardous to the environment and could pose a risk to public health. Due to its complex chemical structure, dye is one of the most difficult constituents in industrial wastewater to treat. The discharges of dyes into receiving waters is one major cause of water pollution. The industrial production of dyes has become highly pollution activity in recent decades. Wastewater from dye houses can have strong impacts on the aquatic environment. In recent years, regulations on dye pollutants are becoming more and more stringent worldwide. Thus, dyes in wastewater have to be removed completely before discharged into receiving waters.
Problem statement: Since, some dyes and their metabolites are mutagenic, carcinogenic and potentially dangerous to the health of living creatures, the released of wastewaters with a high concentration of dye compounds into the environment is considered as one of the important environmental problems. The released of the wastewaters contains dye material into receiving waters such as lakes and rivers decreases light transmission, soluble oxygen and increases $\mathrm{COD}$ and in this way disturbs the marine life. In addition, researchers have found that some dyes can produce carcinogenic aromatic amines during the process of reductive degradation. The industry used a number of dyes, chemicals, auxiliary chemicals and sizing materials in the processing of textiles. It is estimated that 280,000 tons of textile dyes are discharged from the textile industry every year. The average dyeing rate is more than $90 \%$ in the dyeing process while $10 \%$ is the rate of residual dyeing rate in finishing water which is the main source of water pollution (Mohamed et al., 2014).

Background of research: The treatment of textile dyeing wastewater by traditional methods has proven to be

Corresponding Author: Geraldine Chan Sue Ching, Faculty of Chemical Engineering, Universiti Teknologi MARA (UiTM), 94300 Kota Samarahan, Sarawak, Malaysia, geraldinechansc@uitm.edu.my 
ineffective for many waste water treatment facilities. Some previous research has indicated that biological treatment of textile waste water has low degradation efficiency due to the presence of biological inert matter combined with high molecular dye stuff. On the other hand, physical adsorption is effective in removing non biodegradable pollutants but it is an expensive method and it is difficult for adsorbent regeneration (Nordin et al., 2013). Activated carbon adsorption treatment has been proven to be an effective replacement for combined biological and chemical treatment because it depends on the type of carbon and the characteristic of wastewater (Bangash and Manaf, 2005). Coagulation and flocculation methods are widely used for wastewater treatment as these methods are efficient and simple to operate. However, most of the dye stuffs are designed to withstand environmental conditions such a slight, $\mathrm{pH}$ effect and microbial attack (Bangash and Manaf, 2005).

Objective of study: Therefore, the aim of this study is: to determine the effectiveness of coagulation-flocculation method for the removal of color from the textile wastewater using different types of coagulants. To focus on the study on the effect of coagulants on color removal, $\mathrm{pH}$, coagulant dosage on settling time and the effect of flocculation speed and time to obtain the optimum condition of the highest removal of color reactive dye.

Literature review: The available literature shows a large number of well-established conventional decolorization methods involving physico-chemical, chemical and biological process as well as some of new emerging techniques like sonochemical or advanced oxidation process. However, there is no single economically and technically viable method to solve this problem and usually two or three methods have to be combined in order to achieve adequate level of color removal (Robinson et al., 2001). Researches on chemical coagulation-flocculation is observed as one of the most practiced technology.

Most current practices for wastewater decolorization treatment fall into four main classes which are physical or physico-chemical techniques, chemical techniques, biological techniques and electrochemical techniques. Each technique has a specific application and distinct advantages and disadvantages. As a result, each method has to be evaluated, according to cost, application and performance relative to desired goal. Although, no treatment technology has universal application, combination of one or two is generally employed depending on wastewater characteristics (Joshi et al., 2004; Madhav et al., 2018; Verma et al., 2012).
Physical or physico-chemical techniques: Plenty of physico-chemical methods in the form of pretreatment, post treatment or main treatment have been investigated by various researchers throughout the world. The example of physical or physico-chemical methods are precipitation, coagulation/flocculation, ion exchange, adsorption and membrane separation. These remove or separate the colour physically and result in need for solid waste disposal (Joshi et al., 2004).

Coagulation and flocculation: Coagulation and flocculation operations are among the most effective techniques of chemical wastewater treatment and they are frequently used in the treatment of industrial effluent as they require short interment times and are easy to manage. Over the years, coagulation has been the only economically feasible method for colour removal. The primary treatment in a conventional wastewater treatment scheme consists of coagulation and flocculation which removes the colloidal particles of colour, turbidity and bacteria.

Coagulation is used for the removal of the waste materials in suspended or colloidal form that do not settle out on standing or may settle by taking a very long time. In water treatment, coagulation as pretreatment is regarded as the most successful pretreatment (Leiknes, 2009). The most commonly used coagulants in wastewater treatment processes include Aluminium Sulphate or Alum $\left(\mathrm{Al}_{2}\left(\mathrm{SO}_{4}\right)_{3} \cdot 18 \mathrm{H}_{2} \mathrm{O}\right)$, lime $\left(\mathrm{Ca}(\mathrm{OH})_{2}\right)$ and ferric salts such as Ferric Sulphate $\left(\mathrm{Fe}_{2}\left(\mathrm{SO}_{4}\right)_{3} .7 \mathrm{H}_{2} \mathrm{O}\right)$ or Ferric Chloride $\left(\mathrm{FeCl}_{3} .7 \mathrm{H}_{2} \mathrm{O}\right.$ ) (Abu Hassan et al., 2009; Joshi et al., 2004; Madhav et al, 2018; Verma et al, 2012).

Synthetic organic coagulants: These polymer coagulants are highly charged cationic polyelectrolytes and promote precipitation of dye residues, forming small insoluble color particles. These small particles are removed using a suitable solid or liquid separation process. These often completely eliminate the need for the large amounts of aluminium or iron-based salts traditionally used (Cooper, 1995).

Adsorption: Adsorption techniques have received attention in recent years due to their low price and their effectiveness in the elimination of contaminants (Yagub et al., 2014). Adsorption is the phenomenon by which the molecules of the gas, vapor, liquid spontaneously concentrate at contacting surface without undergoing any reaction. It is an effective method for lowering the concentration of dissolved organics in an effluent. The use of any adsorbent, whether ion-exchanger, activated carbon or high surface area 
inorganic material for removing species from a liquid stream depends on the equilibrium between the adsorbed and the free species. The various adsorbents reported in literature for the removal of color from textile effluent are as follows.

\section{MATERIALS AND METHODS}

Activated carbon: Activated carbon has been evaluated extensively for the treatment of different classes of dyes such as acid, direct, basic, disperse, reactive, etc. and is now the most widely used adsorbent for dyes. The molecular structure of a dye has a significant effect on the extent to which it will be absorbed with decreasing solubility and polarity of the dye favoring absorbability on carbon. Disperse dyes, vat dyes and pigments have such low solubility in water that their rate of adsorption on carbon is prohibitively slow at room temperature. On the other hand, water-soluble dyes such as acid, basic, direct, metallized mordant and reactive dyes are also not readily adsorbed on carbon. One of the main reasons for the observed poor adsorption is the polar nature of these dye's vs. the non-polar nature of carbon. Hence, the carbon adsorption of dyes is neither efficient nor economical when used alone. However, when used in combination with polymer flocculation, chemical coagulation or biodegradation it becomes a very useful polishing step for efficient dye removal. It is influenced by physical and chemical factors such as dye-adsorbents interactions, surface area of adsorbent, particle size, temperature, $\mathrm{pH}$ and contact time (Anjaneyulu et al., 2005; Patel and Vashi, 2010). Activated carbon is the most commonly used adsorbent and can be very effective for many dyes (Walker and Weatherley, 1997). However, efficiency is directly dependent upon the type of carbon material used and wastewater characteristics (Robinson et al., 2001; Joshi et al., 2004; Madhav et al., 2018; Verma et al., 2012).

Bio adsorbents: In recent years, investigations have been undertaken to evaluate inexpensive alternate materials of biological origin as potential adsorbents for dyes which include chitin, chitosan (Cooper, 1995; Smith et al., 1993), sawdust (Asfour et al., 1985), carbonized wool, activated sludge, wood bark, rice husk and cotton waste (McKay et al., 1987).

Biomass: Because of its low cost and wide spread availability, biomass has been extensively investigated to remove cooler and has shown some promising result (Yang et al., 1988). Biomass is refers to dead plant and animal matters such as agriculture, forest, fermentation and shellfish byproducts or wastes. Biomass decolorizes wastewater by adsorption and ion exchange mechanisms. Unfortunately, without prior chemical modification these materials uniformly have very low adsorption capacities for anionic dyes. There have been several studies reported on chemical modification of celluloses and ligno-celluloses extracted from cotton waste, sawdust and corn stalks (Laszlo, 1994).

Chitin and chitosan: Chitin, a polysacharide is very similar in structure to cellulose, being composed of poly 2-acetamido-2-dioxy-D-glucose. Chitosan is a well-known derivative of chitin produced by the deacetylation of chitin which is a natural biopolymer extracted from the shell of arthropods (Cooper, 1995). Due to its unique molecular structure, chitosan has an extremely high affinity for many classes of dyes including disperse, direct, reactive, acid, vat, sulphur and naphthol. The rate of the diffusion of dyes in chitosan is similar to that in cellulose (Joshi et al., 2004; Madhav et al., 2018 and Verma et al., 2012).

Microbial biomass: The uptake or accumulation of chemicals is termed as biosorption. Dead bacteria, yeast and fungi have all been used for the purpose of the decolorizing dye containing effluents (Zhou and Zimmerman, 1993; Kumar et al., 1998). Depending on the dye and the species of microorganisms used, different binding rates and capacities were found. The use of biomass has its advantages, especially, if the dye containing effluent is very toxic (Joshi et al., 2004; Madhav et al., 2018 and Verma et al., 2012).

Unmodified lignocellulose biomass: Gurumalesh and Thangavela, Dohanyas et al. McKay et al. (1987) had examined the wood bark, rice husk and cotton waste for the availability to bind Congo red (a divalent anion) and observed negligible amounts of adsorption. Poots et al. showed that the wood could absorb acid dyes successfully but long contact period is required to reach equilibrium. Similarly, McKay et al. (1987) reported that wood shavings to have a capacity for Congo red of 0.001 $\mathrm{mol} / \mathrm{kg}$. The binding on Acid Blue 25 to sugarcane bagasse is slow and the capacity is only $0.05 \mathrm{~mol} / \mathrm{kg}$. Maize (corn) (El-Geundi, 1991) also binds Acid Blue 25 slowly, requiring more than $3 \mathrm{~h}$ to reach the equilibrium (Joshi et al., 2004).

Inorganic adsorbents: In recent years, investigations have been undertaken to evaluate inexpensive inorganic materials as potential adsorbents for dyes which include peat (Ramakrishna and Viraraghavan, 1996), fly ash 
(Khare et al., 1987), bentonite (McKay et al., 1987), calcium metasilicate (Khare et al., 1988), activated aluminium (Rodman, 1971), clay and bauxite (McKay, 1979). The use of bentonite for basic dyes and anthracite charcoal for acid yellows are also known (Pillai, 1997). The use of inorganic adsorbents, such as high surface area silica, cinder ash and clays has been tried for a range of dyes. Silica was found to be reasonably effective for treating effluents containing basic dyes. Again, the process has little effect on the major inorganic charge of the effluent. The use of cinder ash appears to be a cost-effective solution where a readily available supply of the ash is found locally and the effluent does not contain reactive dyes (Joshi et al., 2004).

Polymer waste: Polymers are also capable of adsorbing the residual dyestuff from the textile effluent. Polyamide which can be dyed with most of the common dyestuff classes and has reactive groups available is a primary candidate in this respect (Gartner et al., 1996). The waste polyamide fibers or plastics can be used as dye cleaners by suitably degrading the polyamide to bio functional low molecular fragments with terminal reactive amino and carboxyl groups important for dye uptake (Joshi et al., 2004).

Complexometric technique: Cucurbiturial is a cyclic polymer of glycoluril and the formaldehyde, so, named because its structure is shaped like a pumpkin (Karcher et al., 1999) (a member of the plant family Cucurbitaceae). Cucurbilite showed extraordinarily good sorption capacity for various types of textiles dyes (Buschmann et al., 1992). It is known to form host guest complexes with aromatic compounds and this may be the mechanism for reactive dye adsorption. To be industrially feasible, it needs to be incorporated into fixed bed sorption filters. The high cost is a disadvantage (Joshi et al., 2004).

Membrane filtration process: Selection of an appropriate membrane filtration process such as reverse osmosis, nanofiltration ultrafiltration or microfiltration depends on the features of the waste product. The utilisation of membrane technology for dye removal from wastewater is very effective as reported by various researchers (Ledakowicz et al., 2001).

Reverse osmosis: Membranes used for this process retention rates of $90 \%$ or more for the majority of ionic compounds and create a good class of permeate. In reverse osmosis, the removal of color and the removal of chemical auxiliaries from the textile's effluents can be performed in one step (Dasgupta et al., 2015).
Nanofiltration: This technique is used for the remediation of colored textile wastewater from textile facilities. A blend of nanofiltration along with adsorption may be required for the treatment of textile effluents (Chakraborty et al., 2003).

Ultrafiltration: Ultrafiltration partially removes dyes from textile effluents (Watters et al., 1991). Ultrafiltration can be exclusively applied as a pretreatment for reverse osmosis or together with a biological reactor (Mignani et al., 1999).

Microfiltration: This process is appropriate for handling dye baths that contain pigment dyes (Al-Malack and Anderson, 1997) and for the subsequent rinsing of the baths. It may also be applied for pretreating for nanofiltration or reverse osmosis (Sadr Ghayeni et al., 1998).

Chemical techniques: Chemical methods mainly involve use of oxidising agents such as Ozone $\left(\mathrm{O}_{3}\right)$, Hydrogen peroxide $\left(\mathrm{H}_{2} \mathrm{O}_{2}\right)$ and permanganate $\left(\mathrm{MnO}_{4}\right)$ to change the chemical composition of compound or group of compounds, examples dyes (Metcalf and Eddy, 2003). These technologies can remove the color from the effluent by breaking down the dye into simpler fragments and destroy the chromophore responsible for color. The examples that using this technique are ozonolysis, chemical oxidation or reduction, etc (Verma et al., 2012).

Chemical oxidation: Many dyes are effectively decolorized by using chemical oxidizing agents and found to hold potential for future use in the textile industry. There are many studies on the usage of different agents such as chlorination or flocculation, chlorine dioxide treatment, ozonation use of hydrogen peroxide with other salts (Fenton's reagent), permanganate, etc. Chemical oxidation eliminates the dye from the effluent by breaking the aromatic ring of the dye molecules (Raghavacharya, 1997).

Chlorination and flocculation: Coagulation and flocculation operations are among the most effective techniques of chemical wastewater treatment and they are frequently used in the treatment of wastewater as they require short interment times are easy to manage. The most commonly used coagulants in wastewater treatment process include Aluminium Sulfate or alum $\left(\mathrm{Al}_{2}\left(\mathrm{SO}_{4}\right)_{3} \cdot 18 \mathrm{H}_{2} \mathrm{O}\right)$, lime $\left(\mathrm{Ca}(\mathrm{OH})_{2}\right)$ and ferric salts such as Ferric Sulfate $\left(\mathrm{Fe}_{2}\left(\mathrm{SO}_{4}\right)_{3} .7 \mathrm{H}_{2} \mathrm{O}\right)$ or Ferric Chloride $\left(\mathrm{FeCl}_{3} .7 \mathrm{H}_{2} \mathrm{O}\right)$ (Abu Hassan et al., 2009).

Chlorine dioxide: Chlorine dioxide is less reactive than chlorine and has been claimed to give rise to fewer side reactions (Cooper, 1995). It is showed in the experimental 
study, however, it does not decolorize dye waste efficiently to consent conditions as it has no effect on some dye classes such as vat dyes. Nevertheless, chlorine dioxide is highly effective against reactive, direct, disperse and anionic premetallized dyes. It could be used as a polishing treatment (Joshi et al., 2004).

Ozonation: Ozone is very worthy oxidizing agent as it is highly unstable as compared to chlorine and $\mathrm{H}_{2} \mathrm{O}_{2}$. Ozone oxidation is capable of degrading phenols, pesticides, chlorinated hydrocarbons and other aromatic hydrocarbons and other aromatic hydrocarbons ( $\mathrm{Lin}$ and Lin, 1993; Xu et al., 1999). A short half-life is the main drawback of ozonation. The pace of ozone breakdown increases in an alkaline environment, so, vigilant observation of effluent's $\mathrm{pH}$ is essential (Slokar and Le Marechal,1998; De Souza et al., 2010).

Fenton's reagent: The use of Fenton's reagent is an appropriate chemical method for handling effluents that are resistant to biological remediation or are toxic to biological strains (Kim et al., 2004; Slokar and Le Marechal, 1998). However, sludge production from the flocculation produced by the reagent and the dye molecules is the major disadvantage of this technique (Joshi et al., 2004).

Electrochemical destruction: In this process, no sludge is generated as it requires little utilization of chemicals. The degraded metabolites are normally not dangerous, thus, making it safe for treated effluents to be discharged into receiving water bodies. It is an effective and inexpensive technique for the elimination of the degraded dyes (Martinez-Huitle and Brillas, 2009; Pelegrin et al., 1999).

Biological techniques: Biological treatment involves the aerobic (in presence of $\mathrm{O}_{2}$ ) or anaerobic (in absence of $\mathrm{O}_{2}$ ) degradation of organic substances by microorganisms and has been widely researched and reviewed (Sharon et al., 1996).

Aerobic treatment: Aerobic biological treatment using activated sludge is one of the most commonly used treatment methods for wastewater generated from industrial wastewater, especially, from textile dyeing operations. Normally, this removes the biodegradable components of the effluent, example carbohydrates, waxes and the readily degrable auxiliary compounds, although, more complex xenobiotic compounds such as dyes and surfactants remain as it is.

Reports on the use of bacterial degradation of azo dyes are very few, although, it has been found that some organisms are able to reduce the presence of dyes.
Pseudomonas aeruginosa was able to decolorize a commercial tannery and textile dye, Navitan Fast Blue SSR, in the presence of glucose under aerobic condition (Garg and Tripathi, 2007; Chaudhari et al., 2017; Kalyani et al., 2009; Mansour et al., 2007; Nachiyar and Rajkumar, 2003; Suzuki et al., 2001) also reported aerobic degradation of dye by different biological strains (Joshi et al., 2004; Madhav et al., 2018; Verma et al., 2012).

Anaerobic treatment: In anaerobic conditions, the azo reduction is attained by breaking the azo bond, however, toxic amines are produced. Under anaerobic conditions, dyes are readily cleaved producing amines which are stable biotransformation products of metabolism (Bhatt et al., 2005).

Decolorization using cultures of bacteria, fungi, algae and yeast: Decolorization of dyes by bacterial strains was initially performed by azoreductase catalyzed anaerobic reduction or breakage of azo bonds followed by aerobic or anaerobic degradation pf the resulting aromatic amines by a mixed bacterial community (Singh et al., 2017; Sponza and Isik, 2005). It is found that microbial the decolorization and degradation of dyes as cost-effective and eco-friendly method for removing them from textile effluents. Recent fundamental work has revealed the existence of a wide variety of microorganisms capable of decolorizing equally wide range of dyes (Madhav et al., 2018).

Electrochemical techniques: Electrochemical ion generation is a proven technology for removing color, BOD, COD, TOC, solid such as suspended and dissolved, heavy metals such as chromium, copper and zinc from the textile mill wastewater (Wilcock et al., 1992).

Electrochemical technology is reported to remove acid, disperse and metal complex dyes effectively (Wilcock et al., 1992). The removal of dyes from aqueous solution results from adsorption and degradation of the dyestuff following the interaction with iron electrodes. If metal complex dyes are present, dye solubilizing and charge are the most important factors for successful removal of heavy metals. The $\mathrm{pH}$ has to be adjusted to maximize dye insolubility (Joshi et al., 2004).

Summary: Most of the color removal techniques work either by concentrating the color into sludge or by the partial or complete breakdown of the colored molecule. In principle, decolorizations are achievable by using one or more combination which consists of adsorption, filtration, precipitation, coagulation, flocculation, chemical methods. 
Table 1: Different type of coagulants, dyes and industrial wastewater

\begin{tabular}{llll}
\hline Coagulants & Dye & Industrial wastewater & References \\
\hline $\mathrm{PAC}$, alum, $\mathrm{MgCl}_{2}$ & Reactive dye: RBB, RBBR, RBRF3B & Textile wastewater & Mohamed et al. (2014) \\
$\mathrm{FeCl}_{3}$ & Leachate & Landfill leachate & Ramli and Aziz (2015) \\
$\mathrm{FeSO}_{4}$ & BG dye & Textile dying and paper printing & Mane and Babu (2011) \\
$\mathrm{FeCl}_{3}$ & Leachate & Landfill leachate & Mansour et al. (2007) \\
Alum-P, PAC-P & DR-60 & Dyestuff industrial & Nourmoradi et al. (2015) \\
\hline
\end{tabular}

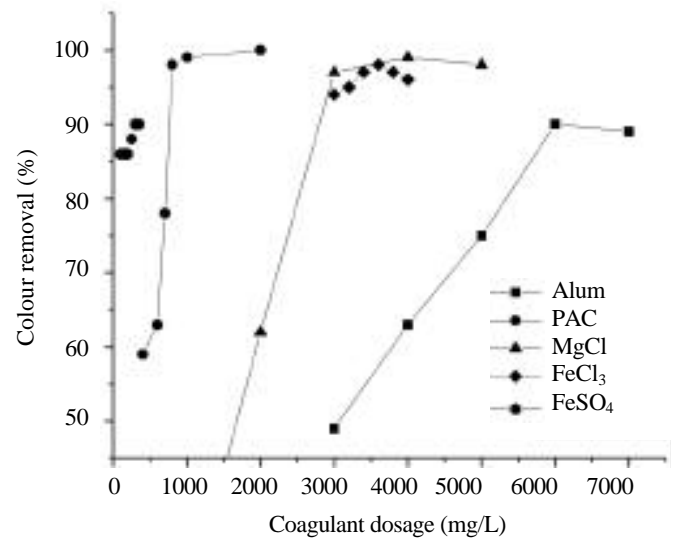

Fig. 1: Colour removal of different dosages of coagulants (Mohamed et al., 2014; Mane and Babu, 2011)

Coagulation or flocculation is the most used widely method for colour removal because of economic feasibility, rapid removal of colour and significant reduction of COD. With rapid changes in dyes and stricter consent limits, these alone do not give completely satisfactory treatments, especially with highly soluble reactive dyes. Moreover, a large quantity of sludge generation containing all the toxic compounds present in the effluent is likely to increase disposal costs substantially and this must be considered before choosing a system (Joshi et al., 2004; Madhav et al., 2018; Verma et al., 2012).

Comparison of coagulants on different effects: The productiveness of various coagulation-flocculation treatments for removing colour in dye solution was studied. The coagulants listed in Table 1 was used to compare the effectiveness of the coagulants in the removal of different types of dyes from different industrial wastewater.

In Fig. 1, it shows the performance of coagulants, Alum, $\mathrm{PAC}, \mathrm{FeCl}_{3}, \mathrm{FeSO}_{4}$ and $\mathrm{MgCl}_{3}$ for colour removal. The most important parameters in coagulationflocculation treatment is coagulant dosage which should be included. These coagulants were compared with different dosage from $50-7,000 \mathrm{mg} / \mathrm{L}$.

Studying on the effect of $\mathrm{pH}$ is important which from this research, optimum $\mathrm{pH}$ for colour removal will be obtained. For this experiment, $\mathrm{pH}$ ranges from 2-12 (Fig. 2).

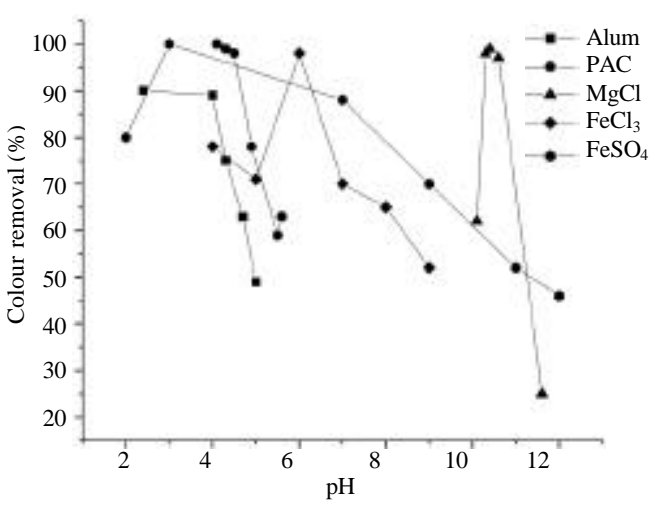

Fig. 2: The effect of $\mathrm{pH}$ on different coagulants (Mohamed et al., 2014; Ramli and Aziz, 2015; Mane and Babu, 2011)

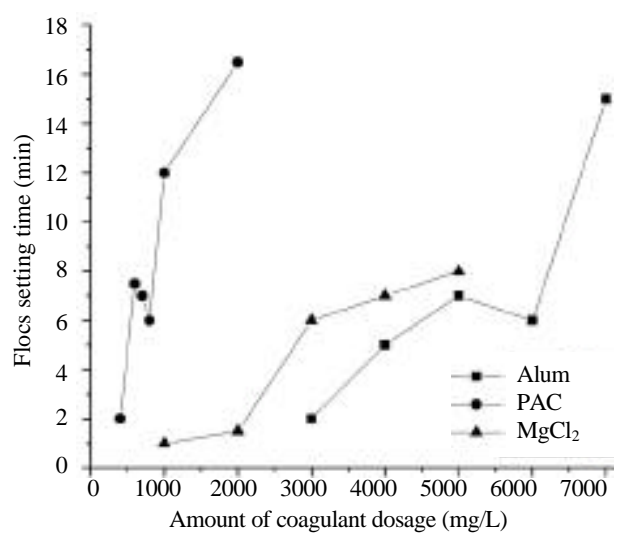

Fig. 3: The effect of $\mathrm{PAC}, \mathrm{MgCl}_{2}$ and alum dosages on flocs settling time (Mohamed et al., 2014)

In Fig. 3 and 4 show the comparison of flocs settling time between $\mathrm{PAC}, \mathrm{MgCl}_{2}, \mathrm{FeCl}_{3}$ and alum. It is essential to study about the settling time which to find whether the coagulan dosage works successfully to settle the dye in wastewater.

The effect of flocculation speed and time for alum-praestol, PAC-praestol and $\mathrm{FeCl}_{3}$ on the dye removal efficiency was shown in Fig. 4 and 5. The flocculation speed for alum-praestol and PAC-praestol from 20-60 rpm for 15 and $30 \mathrm{~min}$, however, speed for $\mathrm{FeCl}_{3}$ is 300 and $50 \mathrm{rpm}$, respectively. 
Fig. 4: The effect of flocculation speed and time (rapid) (Nourmoradi et al., 2015; Mansour et al., 2007)

Fig. 5: The effect of flocculation speed and time (slow) (Nourmoradi et al., 2015; Mansour et al., 2007)

\section{RESULTS AND DISCUSSION}

\section{Recommendation on the different effects}

The effect of coagulants on colour removal: The performance of alum for colour removal is shown in Fig. 1. To achieve $90 \%$ colour removal of reactive dye, $6,000 \mathrm{mg} / \mathrm{L}$ dosages of alum was needed. An initial dosage for alum of $3,000 \mathrm{mg} / \mathrm{L}$ gave an important increasing linear curve until the coagulant dosage achieve $6,000 \mathrm{mg} / \mathrm{L}$ and the curve achieved $90 \%$ of colour removal. The percentage of colour removal increase up to $97 \%$ when $3,000 \mathrm{mg} / \mathrm{L}$ of $\mathrm{MgCl}_{2}$ was used and when the concentration of $\mathrm{MgCl}_{2}$ increased from 1,000-2,000, the percentage of colour removal increased tremendously from $25 \%$ to $62 \%$, according to Fig. 1 by Mohamed et al. (2014). Due to the destabilization of dye particles by excess alum hydrolysis species, the percentage of colour removal decreased with the increasing in the coagulant dosages. At the dosages $800 \mathrm{mg} / \mathrm{L}$ of PAC, percentage colour removal of reactive dye was achieving $>100 \%$. The highest percentage of colour removal was attained when $800 \mathrm{mg} / \mathrm{L} \mathrm{PAC}$ was used but further increase in PAC dosages will lead to a decrease in colour removal as all dyes had been removed at that stage. This problem which excessive coagulant would cause the formation of excessive flocs, in turn would prolong the settling time.

Figure 1 also presents the effect of ferrous Sulphate, $\mathrm{FeSO}_{4}$ with constant lime dosage at $100 \mathrm{mg} / \mathrm{L}$ on colour removal efficiency of $\mathrm{BG}$ from the journal (Mane and Babu, 2011). As the coagulant dosage increased, the colour removal efficiency also increased and above a certain dosage remains constant. The percentage of colour removal increased when the coagulant dosage increases from $200-300 \mathrm{mg} / \mathrm{L}$.

At a constant $\mathrm{pH}$ of 6 , the dosages of $\mathrm{FeCl}_{3}$ varied from 3,000-4,000 mg/L in Fig. 1. As the coagulant dosage increased from $3,000-3,600 \mathrm{mg} / \mathrm{L}$, the removal rates of colour also increased, however, it decreased when the $\mathrm{FeCl}_{3}$ was increasing to $4,000 \mathrm{mg} / \mathrm{L}$. The highest percentage of colour removal for $\mathrm{FeCl}_{3}$ was $3,600 \mathrm{mg} / \mathrm{L}$; the removal rates was $97.77 \%$. Hence, the optimum dosage For $\mathrm{FeCl}_{3}$ was $3,600 \mathrm{mg} / \mathrm{L}$. The removal rates decreased at dosages beyond the optimum due to the overdosing that lead to the coagulation to destabilize which in turn decreased the removal rates.

After combining all the coagulants in one graph, the effective coagulant for colour removal was shown in Fig. 1, the most effective coagulants are $\mathrm{PAC}$ as the rate of removing dye achieve $100 \% . \mathrm{FeCl}_{3}$ and $\mathrm{MgCl}_{2}$ shows their effectiveness also but it still cannot match $\mathrm{PAC}$ and only achieve $99.8 \%$. Other than that, alum and $\mathrm{FeSO}_{4}$ approaching $\mathrm{FeCl}_{3}$ and $\mathrm{MgCl}_{2}$ with their removal rate $90 \%$ of reactive dye and BG dye. Hence, PAC was chosen as the most effective coagulants in wastewater treatment for coagulation-flocculation method.

The effect on pH: Figure 2 shows that from $\mathrm{pH}$ 6.0-6.3, alum soluble. Therefore, in order to minimize the residual of aluminium, it is advantageous for coagulation with alum in this $\mathrm{pH}$ region for sweep flocs coagulation, compared to higher $\mathrm{pH}$ coagulation, it helps to utilize a greater fraction of dissolved positively aluminium charged. When the concentration increased from $5,000-6,000 \mathrm{mg} / \mathrm{L}$, the removal of dye increased tremendously in the $\mathrm{pH}$ range of 2.4-4.3. To destabilize particles by charge neutralization and react with negatively charged colloids, coagulation below pH 7 means that this highly charged aluminium would be available. Figure 2 also shows the range of $10.0-12.0$ was the maximum $\mathrm{pH}$ range for $\mathrm{MgCl}_{2}$. When the 
$\mathrm{MgCl}_{2}$ concentration increased from 1,000-2,000 $\mathrm{mg} / \mathrm{L}$, the removal of dye increased in the range of $25-62 \%$ and it continue to increase for further addition of $\mathrm{MgCl}_{2}$. In the $\mathrm{pH}$ range of $3-5$, the treatment with $1,000 \mathrm{mg} / \mathrm{L}$ of PAC gave $99 \%$ removal of dye. When the concentration of $\mathrm{PAC}$ increased, a phenomenon of two peaks in the $\mathrm{pH}$ range happened which is at the acidic zone between 3-6 and 6-9. For PAC dosage in the acidic zone, the percentage removal of dye was almost $100 \%$.

Figure 2 presents the effect of $\mathrm{pH}$ on th removal of $\mathrm{BG}$ (Ferrous Sulphate, $\mathrm{FeSO}_{4}$ dose $=350 \mathrm{mg} / \mathrm{L}$ ) which the experiment conducted by (Mane and Babu, 2011). From previous studies, it was found that colour is stable at the self of $\mathrm{pH}=2.9$ in the effect of initial $\mathrm{pH}$ on $\mathrm{BG}$ dye. However, with the maximum rate of colour removal of approximately $99.9825 \%$ at $\mathrm{pH}=11$, colour reduction increase as the $\mathrm{pH}$ increases. Due to the structural changes being affected in the dye-molecules, colour removal can cause $\mathrm{pH}$ change alone. Therefore, all further experiments were conducted without adjusting the $\mathrm{pH}$ for $\mathrm{BG}$ removal, since, 2.9 is the self $\mathrm{pH}$ of $\mathrm{BG}$ solution.

Experiment conducted by Ramli and Aziz, 2015, a pH range of 4-9 was choose and $\mathrm{FeCl}_{3}$ and Chitosan was kept constant at their optimum dosages of 3,600 and $60 \mathrm{mg} / \mathrm{L}$, respectively. When $\mathrm{pH}$ increased from $4-9$, the rate of colour removal also increases using $\mathrm{FeCl}_{3}$ and the at a $\mathrm{pH}$ of 6 , the highest percentage of colour removal was $98 \%$ was achieved. The colour removal decreased as the $\mathrm{pH}$ increased from acidic to basic, therefore, for $\mathrm{FeCl}_{3}, \mathrm{pH}$ of 6 is the optimum. In the coagulation process, $\mathrm{pH}$ is responsible for controlling the hydrolysis species where a series of soluble hydrolysis species form with the addition of a metal salts coagulant. Depending on the $\mathrm{pH}$ value of the sample used, these species can either positively charged or negatively charged. A high $\mathrm{pH}$ produces negatively charged species, whereas a low $\mathrm{pH}$ value $<6$ produces positively charged species. This mechanism who's positively charged hydrolysis species can penetrate and destabilize colloidal particles is known as the charge neutralization mechanism.

Most of the coagulants, $\mathrm{PAC}, \mathrm{FeSO}_{4}$, alum and $\mathrm{FeCl}_{3}$ more effective in acidic $\mathrm{pH}$ range but for $\mathrm{MgCl}_{2}$, it was more effective in alkaline region of $\mathrm{pH}$ range. Ramli and Aziz (2015) have explained about the positively and negatively charged where the positive charged penetrate and destabilize the colloidal particles with high $\mathrm{pH}$ value $(>6)$. After the optimum $\mathrm{pH}$ range where it achieves highest rate of removal, the colour removal will be decreased. So, the optimum $\mathrm{pH}$ range was important where we will know the effective coagulants use for the treatment in colour removal of dye.
Table 2: Optimal pH for different coagulants. (Mohammed et al., 2014; Ramli and Aziz, 2015; Mane and Babu, 2011)

\begin{tabular}{lcc}
\hline Coagulant & Coagulant dosage $(\mathrm{mg} / \mathrm{L})$ & Optimal $\mathrm{pH}$ range \\
\hline Alum & 6,000 & $2.0-5.00$ \\
$\mathrm{MgCl}$ & 3,000 & $10.0-12.0$ \\
$\mathrm{PAC}$ & 800 & $4.0-6.00$ \\
$\mathrm{FeCl}_{3}$ & 3,600 & $4.0-9.00$ \\
$\mathrm{FeSO}_{4}$ & 350 & $2.0-12.0$ \\
\hline
\end{tabular}

From Table 2, it presents the optimum $\mathrm{pH}$ range of coagulants PAC treatment are wider than alum treatment. Therefore, compared to the alum treatment, PAC treatment is less sensitive to $\mathrm{pH}$ which is due to the pre-polymerized species that are partially hydrolyzed and already exist in the $\mathrm{PAC}$ solution. In addition, on the optimum $\mathrm{pH}$ range for any of three coagulants investigated, Table 2 shows the different in ratios of disperse dye to reactive dye in the mixed dye solutions do not have any effects. Other coagulants, $\mathrm{FeCl}_{3}$, chitosan and $\mathrm{FeSO}_{4}$ more sensitive to $\mathrm{pH}$ range than PAC.

The effect of coagulants on settling time: The settling time for the treatment with alum and $\mathrm{MgCl}_{2}$ was shorter than the flocs settling time for the treatment with PAC. The flocs settling time for alum dosage of $5,000 \mathrm{mg} / \mathrm{L}$, PAC dosage of $600 \mathrm{mg} / \mathrm{L}$ and $\mathrm{MgCl}_{2}$ dosage of $5,000 \mathrm{mg} / \mathrm{L}$ were 435,420 and $426 \mathrm{sec}$. With the removal of $98 \%$, PAC dosage of $800 \mathrm{mg} / \mathrm{L}$ had settling time of $352 \mathrm{sec}$. The settling time was more than $500 \mathrm{sec}$, although, higher dosage of PAC gave $>98 \%$ of colour removal which is not preferable in the wastewater treatment as it would increase the size of the settling tank. For the coagulant dosage that was studied, the settling time for the treatment using $\mathrm{MgCl}_{2}$ did not exceed $500 \mathrm{sec}$. When $5,000 \mathrm{mg} / \mathrm{L}$ of $\mathrm{MgCl}_{2}$ was used, the longest settling time is $495 \mathrm{sec}$ of the treatment happened, therefore, the flocs formed in the treatment with $\mathrm{MgCl}_{2}$ were larger and easier to resolve than treatment with PAC. Other than the formed using alum and $\mathrm{PAC}$, size of flocs formed using $\mathrm{MgCl}_{2}$ much bigger and suitable size. The removal of 90 dye in settling time of $330 \mathrm{sec}$ was inspected for alum dosages of 6,000 $\mathrm{mg} / \mathrm{L}$. With the settling time exceeded $500 \mathrm{sec}$, the increase of alum dosages leads to lower of colour removal which is $69 \%$ but it is not effective as PAC, although, it has a lower settling time the coagulants. In the wastewater treatment plant, PAC was preferable because it had the most effective percentage of colour removal and lower in settling time. It is also suitable to investigate the reactive dye and at once discovered that as the dye concentration increased, the time needed to reach identical colour removal also increased.

After $60 \mathrm{~min}$ of settling, the effect of settling time presents in Fig. 4 shows that $\mathrm{FeCl}_{3}$ almost complete the 
removal of suspended solids was acquired. The suspended solids of leachate will be removed in this settling tank was investigated by Mansour et al. (2007) on the coagulation-flocculation method. Due to the adsorption of strongly charged partially hydrolyzed metallic ions, the destabilization of colloidal particles happened as the concentration of suspended solids in the raw leachate was considerably high. Which does not happen at higher coagulant dosage, continued adsorption will result in reversal and destabilization of the suspension.

By combining another journal, the effectiveness was shown as this will be used for the future method. To settle the particles, the fewer minutes much better than take a long time to settle. $\mathrm{MgCl}_{2}$ show the fastest to settle down than other coagulants but it needs a more coagulant dosage. However, PAC just needs a little dosage of coagulant to settle but it takes time and settled in $16 \mathrm{~min}$.

The effect on flocculation speed and time: The coagulation test was carried out in combination with Al-P (Alum and Praestol) dosages of 50 and $80 \mathrm{mg} / \mathrm{L}$ and PA-P (PAC and Praestol) dosages of 100 and $400 \mathrm{mg} / \mathrm{L}$, respectively and at $\mathrm{pH} 7$, the initial dye concentration of $100 \mathrm{mg} / \mathrm{L}$. Figure 4, at flocculation time of $15 \mathrm{~min}$, as increase the flocculation speed from $20-40 \mathrm{rpm}$, the dye removal efficiency will be decreased. However, as the flocculation speed increased from 40-60 rpm for alum and $\mathrm{PAC}$, the dye at a mixing time of $30 \mathrm{~min}$ will be increased. Therefore, for Al-P and PA-P, the maximum of dye removal was 98.1 and $99.4 \%$ was acquired at flocculation speed of $20 \mathrm{rpm}$ and time of $15 \mathrm{~min}$, respectively.

In Fig. 4 and 5, also shown the effect of mixing time for $\mathrm{FeCl}_{3}$ on the removal of suspended solids. As compared to other speeds, the highest rate removal of suspended solids for $\mathrm{FeCl}_{3}$ at $300 \mathrm{rpm}$ of rapid mixing and $50 \mathrm{rpm}$ of slow mixing had shown over $98 \%$ of removal but it still not reached $100 \%$ of removal conducted by Mansour et al. (2007).

The alum and PAC were added some coagulant aid to fasten their mixing time which is praestol. So, the results much disappointed as we want to discover the effectiveness in mixing without coagulant aid. Hence, PAC achieves the highest flocculation speed in coagulation method than alum and $\mathrm{FeCl}_{3}$. This alum and PAC use to remove Disperse Red 60 (DR 60) in dyestuff plant. As for $\mathrm{FeCl}_{3}$, it uses to removed colour of leachate in a landfill site.

\section{CONCLUSION}

This study shows different coagulants to remove different dyes which is $\mathrm{PAC}, \mathrm{MgCl}_{2}$, alum, $\mathrm{FeSO}_{4}$ and
$\mathrm{FeCl}_{3}$ removes $\mathrm{RBB}, \mathrm{RBBR}, \mathrm{RBRF} 3 \mathrm{~B}$, leachate, $\mathrm{CR}$ and $\mathrm{BG}$ dye. But these coagulants work on the same objectives, removing colour from industrial wastewater and keep it clean as possible as can. After make a comparison between all of these coagulants, PAC was the most effective to remove the dye because it uses little dosage to reduce the colour of dye to achieved $100 \%$ removal rates using $2,000 \mathrm{mg} / \mathrm{L}$ at $\mathrm{pH} 4.1$ and it also shows the lower in settling time and mixing time which can reduce the cost of electricity on plant.

\section{ACKNOWLEDGEMENT}

The researcher would like to acknowledge the Faculty of Chemical Engineering, Universiti Teknologi MARA, Samarahan Campus for supporting this research.

\section{REFERENCES}

Abu Hassan, M.A., T.P. Li and Z.Z. Noor, 2009. Coagulation and flocculation treatment of wastewater in textile industry using Chitosan. J. Chem. Nat. Resour. Eng., 4: 43-53.

Al-Malack, M.H. and G.K. Anderson, 1997. Use of crossflow microfiltration in wastewater treatment. Water Res., 31: 3064-3072.

Anjaneyulu, Y., N.S. Chary and D.S.S. Raj, 2005. Decolourization of industrial effluents-available methods and emerging technologies-a review. Rev. Environ. Sci. Bio. Technol., 4: 245-273.

Asfour, H.M., O.A. Fadali, M.M. Nassar and M.S. El-Geundi, 1985. Equilibrium studies on adsorption of basic dyes on hardwood. J. Chem. Technol. Biotechnol., 35: 21-27.

Bangash, F.K. and A. Manaf, 2005. Dyes removal from aqueous solution using wood activated charcoal of Bombax cieba tree. J. Chin. Chem. Soc., 52: 489-494.

Bhatt, N., K.C. Patel, H. Keharia and D. Madamwar, 2005. Decolorization of diazo-dye reactive blue 172 by Pseudomonas aeruginosa NBAR12. J. Basic Microbiol., 45: 407-418.

Buschmann, H.J., E. Cleve and E. Schollmeyer, 1992. Cucurbituril as a ligand for the complexation of cations in aqueous solutions. Inorg. Chem. Acta, 193: 93-97.

Chakraborty, S., M.K. Purkait, S.D. Gupta, S. De and J.K. Basu, 2003. Nanofiltration of textile plant effluent for color removal and reduction in COD. Sep. Purif. Technol., 31: 141-151.

Chaudhari, A.U., D. Paul, D. Dhotre and K.M. Kodam, 2017. Effective biotransformation and detoxification of anthraquinone dye reactive blue 4 by using aerobic bacterial granules. Water Res., 122: 603-613. 
Cooper, P., 1995. Colour in Dyehouse Effluent. Bradford Society of Dyers and Colourists, Bradford, UK., ISBN:9780901956699, Pages: 200.

Dasgupta, J., J. Sikder, S. Chakraborty, S. Curcio and E. Drioli, 2015. Remediation of textile effluents by membrane based treatment techniques: A state of the art review. J. Environ. Manage., 147: 55-72.

De Souza, S.M.A.G.U., K.A.S. Bonilla and A.A.U. De Souza, 2010. Removal of COD and Color from hydrolyzed textile azo dye by combined ozonation and biological treatment. J. Hazard. Mater., 179: 35-42.

El-Geundi, M.S., 1991. Colour removal from textile effluents by adsorption techniques. Water Res., 25 : 271-275.

Garg, S.K. and M. Tripathi, 2017. Microbial strategies for discoloration and detoxification of Azo dyes from textile effluents. Res. J. Microbiol., 12: 1-19.

Gartner, R., W. Muller, G. Schultz and T. Lehr, 1996. New sorption materials based on specially prepared polyamide waste as adsorptive cleansers from dyehouse effluent. Melliand Textileber., 77: 19-21.

Joshi, M., R. Bansal and R. Purwar, 2004. Colour removal from textile effluents. Indian J. Fibre Text. Res., 29: 239-259.

Kalyani, D.C., A.A. Telke, R.S. Dhanve and J.P. Jadhav, 2009. Ecofriendly biodegradation and detoxification of reactive red 2 textile dye by newly isolated Pseudomonas sp. SUK1. J. Hazard. Mater., 163: 735-742.

Karcher, S., A. Kornmuller and M. Jekel, 1999. Removal of reactive dyes by sorption/complexation with cucurbituril. Water Sci. Technol., 40: 425-433.

Khare, S.K., K.K. Panday, R.M. Srivastava and V.N. Singh, 1987. Removal of victoria blue from aqueous solution by fly ash. J. Chem. Technol. Biotechnol., 38: 99-104.

Khare, S.K., R.M. Srivastava, K.K. Pandey and V.N. Singh, 1988. Removal of basic dye (Crystal Violet) from water using wollastonite as absorbent. Environ. Technol. Lett., 9: 1163-1172.

Kim, T.H., C. Park, J. Yang and S. Kim, 2004. Comparison of disperse and reactive dye removals by chemical coagulation and Fenton oxidation. J. Hazard. Mater., 112: $95-103$.

Kumar, M.N.V.R., T.R. Sridhar, K.D. Bhavani and P.K. Dutta, 1998. Trends in color removal from textile mill effluents. Colorage, 40: 25-34.

Laszlo, J.A., 1994. Removing acid dyes from textile wastewater using biomass for decolorization. Am. Dyest. Rep., 83: 17-21.

Ledakowicz, S., M. Solecka and R. Zylla, 2001. Biodegradation, decolourisation and detoxification of textile wastewater enhanced by advanced oxidation processes. J. Biotechnol., 89: 175-184.
Leiknes, T., 2009. The effect of coupling coagulation and flocculation with membrane filtration in water treatment: A review. J. Environ. Sci., 21: 8-12.

Lin, S.H. and C.H. Lin, 1993. Treatment of textile waste effluents by ozonation and chemical coagulation. Water Res., 27: 1743-1748.

Madhav, S., A. Ahamad, P. Singh and P.K. Mishra, 2018. A review of textile industry: Wet processing, environmental impacts and effluent treatment methods. Environ. Quality Manage., 27: 31-41.

Mane, V.S. and P.V. Babu, 2011. Evaluation of performance of coagulation/flocculation method for the removal of dyes from aqueous solutions. Proceedings of the International Conference on Current Trends in Technology (NUiCONE-2011), Institute of Technology, December 8-10, 2011, Nirma University, Ahmedabad, India, pp: 1-6.

Mansour, H.B., D. Corroler, D. Barillier, K. Ghedira and L. Chekir et al., 2007. Evaluation of genotoxicity and pro-oxidant effect of the azo dyes: Acids yellow 17, violet 7 and orange 52 and of their degradation products by Pseudomonas putida mt-2. Food Chem. Toxicol., 45: 1670-1677.

Martinez-Huitle, C.A. and E. Brillas, 2009. Decontamination of wastewaters containing synthetic organic dyes by electrochemical methods: A general review. Applied Catal. B-Environ., 87: 105-145.

McKay, G., 1979. Waste color removal from textile effluents. Am. Dyest. Rep., 68: 29-34.

McKay, G., G. Ramprasad and P. Mowli, 1987. Desorption and regeneration of dye colours from low-cost materials. Water Res., 21: 375-377.

Metcalf and Eddy, 2003. Wastewater Engineering: Treatment and Reuse. 4th Edn., McGraw-Hill, New York.

Mignani, M., G. Nosenzo and A. Gualdi, 1999. Innovative ultrafiltration for wastewater reuse. Desalinat., 124 : 287-292.

Mohamed, R.M.S.R., N.M. Nanyan and N.A. Rahman, 2014. Colour removal of reactive dye from textile industrial wastewater using different types of coagulants. Asian J. Appl. Sci., 2: 650-657.

Nachiyar, C.V. and G.S. Rajkumar, 2003. Degradation of a tannery and textile dye, navitan fast blue S5R by Pseudomonas aeruginosa. World J. Microbiol. Biotechnol., 19: 609-614.

Nordin, N., S.F.M. Amir, Riyanto and M.R. Othman, 2013. Textile industries wastewater treatment by electrochemical oxidation technique using metal plate. Int. J. Electrochem. Sci., 8: 11403-11415. 
Nourmoradi, H., Z. Rahmati, M. Javaheri, K. Moradnejadi and Z. Noorimotlagh, 2015. Effect of Praestol as a coagulant-aid to improve coagulation-flocculation in dye containing wastewaters. Global Nest J., 18: $38-46$.

Patel, H. and R.T. Vashi, 2010. Treatment of textile wastewaterby adsorption and coagulation. J. Chem., 7: 1468-1476.

Pelegrini, R., P. Peralta-Zamora, A.R. De Andrade, J. Reyes and N. Duran, 1999. Electrochemically assisted photocatalytic degrada-tion of reactive dyes. Appl. Catal. B Environ., 22: 83-90.

Pillai, J., 1997. Flocculants and coagulants: The keys to water and waste management in Aggregate production. Nalco Company, Naperville, Illinois. http://www.aniq.org.mx/pqta/pdf/Flocculants\%20a nd\%20Coagulants\%20NALCO\%20(LIT).pdf

Raghavachary, C., 1997. Colour removal form industrial effluents: A comparative review of available technologies. Chem. Eng. World, 32: 53-54.

Ramakrishna, K.R. and T. Viraraghavan, 1996. Dye removal using peat. Am. Dyest. Rep., 85: 28-34.

Ramli, S.F. and H.A. Aziz, 2015. Use of ferric chloride and chitosan as coagulant to remove turbidity and color from landfill leachate. Applied Mech. Mater. Vols, 773-774: 1163-1167.

Robinson, T., G. McMullan, R. Marchant and P. Nigam, 2001. Remediation of dyes in textile effluent: A critical review on current treatment technologies with a proposed alternative. Bioresour. Technol., 77: 247-255.

Rodman, C.A., 1971. Removal of colour from textile dye wastes. Text. Chem. Color, 11: 239-247.

Sadr Ghayeni, S.B., P.J. Beatson, R.P. Schneider and A.G. Fane, 1998. Water reclamation from municipal wastewater using combined microfiltration-reverse osmosis (ME-RO): Preliminary performance data and microbiological aspects of system operation. Desalinat., 116: 65-80.

Sarasa, J., M.P. Roche, M.P. Ormad, E. Gimeno and A. Puig et al., 1998. Treatment of a wastewater resulting from dyes manufacturing with ozone and chemical coagulation. Water Res., 32: 2721-2727.

Sharon, F., D. Gregory and J.M. Donald, 1996. Chemical Pretreatment and Aerobic-Anaerobic Degradation of Textile Dye Wastewater. In: Environmental Chemistry of Dyes and Pigments, Reife, A. and H.S. Freeman (Eds.). Wiley, Hoboken, New Jersey, USA., ISBN: 9780471589273, pp: 75-104.
Singh, P., R. Jain, N. Srivastava, A. Borthakur and D.B. Pal et al., 2017. Current and emerging trends in bioremediation of petrochemical waste: A review. Crit. Rev. Environ. Sci. Technol., 47: 155-201.

Slokar, Y.M. and A.M. Le Marechal, 1998. Methods of decoloration of textile wastewaters. Dyes Pigm., 37: 335-356.

Smith, B., T. Koonce and S. Hudson, 1993. Decolorizing dye wastewater using chitosan. Am. Dyest. Rep., 82: 18-36.

Sponza, D.T. and M. Isik, 2005. Reactor performances and fate of aromatic amines through decolorization of Direct Black 38 dye under anaerobic/aerobic sequentials. Process Biochem., 40: 35-44.

Suzuki, Y., T. Yoda, A. Ruhul and W. Sugiura, 2001. Molecular cloning and characterization of the gene coding for azoreductase from Bacillus sp: OY1-2 isolated from soil. J. Biol. Chem., 276: 9059-9065.

Verma, A.K., R.R. Dash and P. Bhunia, 2012. A review on chemical coagulation/flocculation technologies for removal of colour from textile wastewaters. J. Environ. Manage., 93: 154-168.

Walker, G.M. and L.R. Weatherley, 1997. Adsorption of acid dyes on to granular activated Carbon in fixed beds. Water Res., 31: 2093-2101.

Watters, J.C., E. Biagtan and O. Senlar, 1991. Ultrafiltration of a textile plant effluent. Separat. Sci. Tech., 26: 1295-1313.

Wilcock, A., M. Brewster and W. Tincher, 1992. Using electrochemical technology to treat textile wastewater: Three case studies. Am. Dyest. Rep., 81: 15-16.

Xu, Y., R.E. Lebrun, P.J. Gallo and P. Blond, 1999. Treatment of textile dye plant effluent by nanofiltration membrane. Sep. Sci. Technol., 34: 2501-2519.

Yagub, M.T., T.K. Sen, S. Afroze and H.M. Ang, 2014. Dye and its removal from aqueous solution by adsorption: A review. Adv. Colloid Interface Sci., 209: 172-184.

Yang, Y., C.M. Ladisch and M.R. Ladisch, 1988. Cellulosic adsorbents for treating textile mill effluents. Enzyme Microb. Technol., 10: 632-636.

Zhou, W. and W. Zimmermann, 1993. Decolorization of industrial effluents containing reactive dyes by actinomycetes. FEMS. Microbiol. Lett., 107: 157-161. 